\title{
Comparison of obstetric outcomes of pregnant women with isolated proteinuria according to proteinuria severity
}

\author{
Mehmet Özgür Akkurt', Bora Coşkun², Tuğberk Güçlü', Kaan Pakay', Engin Korkmazer' \\ ${ }^{1}$ Perinatology Clinic, Bursa Postgraduate Training and Research Hospital, Bursa, Turkey \\ ${ }^{2}$ Gynecology and Obstetrics Clinic, Gülhane Training and Research Hospital, Ankara, Turkey
}

\begin{abstract}
Objective: To compare the obstetric outcomes of women who were found to have isolated gestational proteinuria (IGP) according to the severity of 24-hour proteinuria.

Methods: The women who were found to have IGP between January 1, 2014 and June 1, 2018 at the Bursa Yüksek İhtisas Training and Research Hospital were included in our retrospective study. The study population was divided into 3 groups according to the proteinuria severity: Group 1: Proteinuria at physiological level $(<300 \mathrm{mg} / \mathrm{day}, \mathrm{n}=$ 60); Group 2: Mild proteinuria (between $300 \mathrm{mg}$ and $3000 \mathrm{mg} /$ day, $\mathrm{n}=49$ ); Group 3: Proteinuria at nephrotic level ( $\geq 3000 \mathrm{mg} /$ day, $\mathrm{n}=28$ ).

Results: There was no difference among 3 groups in terms of maternal age, gravida and the number of living children. The mean proteinuria amount was the highest in the group with nephrotic level $(216 \pm 73 \mathrm{mg} /$ day in Group 1, 849 $\pm 119 \mathrm{mg} /$ day in Group 2, and 9055 \pm $1011 \mathrm{mg} /$ day in Group 3, respectively; $\mathrm{p}<0.05)$. Preeclampsia (PE) incidence was higher in Group 3 (6.6\% in Group 1, 47\% in Group 2 and $64 \%$ in Group 3, respectively; $\mathrm{p}<0.05$ ). The period elapsed between the diagnoses of IGP and PE was the shortest in Group 3 (21.2 \pm 4.9 days in Group 1, 16.4 \pm 4.7 days in Group 2, and 7.8 \pm 2.2 days in Group 3, respectively; $\mathrm{p}<0.05$ ). There was no significant correlation between proteinuria severity and birth weight and the period elapsed between the diagnoses of IGP $(r=0.68)$ and PE $(r=0.79)$.

Conclusion: While IGP increases the incidence of poor perinatal outcomes such as intrauterine growth retardation, low birth weight and iatrogenic preterm birth, it was also found that PE incidence is higher, diagnosis week is earlier and the period between IGP and PE diagnoses are shorter in women with proteinuria at nephrotic level than those with less severe proteinuria.
\end{abstract}

Keywords: Low birth weight, interval, isolated gestational proteinuria, preeclampsia.

\section{Özet: İzole proteinüri saptanan gebe kadınların obstetrik sonuçlarının proteinüri şiddetine göre karşılaştırılması}

Amaç: İzole gestasyonel proteinüri (İGP) saptanan kadınların obstetrik sonuçlarının 24 saatlik proteinüri şiddetine göre karşılaştırılması.

Yöntem: Retrospektif çalışmamıza Bursa Yüksek İhtisas Eğitim ve Araştırma Hastanesinde 1 Ocak 2014 - 1 Haziran 2018 tarihleri arasında İGP saptanan kadınlar dahil edildi. Çalışma popülasyonu proteinüri şiddetine göre 3 gruba ayrıldı: Grup 1, fizyolojik düzeyde proteinüri ( $<300 \mathrm{mg} /$ gün, n=60); Grup 2, hafif proteinüri (300$3000 \mathrm{mg} /$ gün arası, n=49); Grup 3, nefrotik düzeyde proteinüri ( $\geq 3000 \mathrm{mg}, \mathrm{n}=28$ ).

Bulgular: Her 3 grup arasında maternal yaş, gravida ve yaşayan çocuk sayısı açısından fark bulunmadı. Nefrotik düzeydeki grupta ortalama proteinüri miktarı en fazla saptandı (sırasıyla Grup 1'de $216 \pm 73 \mathrm{mg} /$ gün, Grup 2'de 849 $\pm 119 \mathrm{mg}$ /gün, Grup 3'de $9055 \pm 1011 \mathrm{mg} /$ gün; $\mathrm{p}<0.05$ ). Grup 3'de preeklampsi (PE) gelişme sıklığ1 daha fazla idi (sırasılyla Grup 1'de \%6.6, Grup 2'de $\% 47$, Grup 3'de \%64; p<0.05). IGP ile PE tanısı arasında geçen süre Grup 3'de daha kısa saptandı (sırasıyla Grup 1'de 21.2 \pm 4.9 gün, Grup 2'de 16.4 \pm 4.7 gün, Grup 3'de 7.8 \pm 2.2 gün; $\mathrm{p}<0.05$ ). Proteinüri şiddeti ile doğum ağırlığı ve IGP (r=0.68) ile PE tanıs1 arasında geçen süre arasında $(r=0.79)$ anlamlı korelasyon saptanmadi.

Sonuç: IGP, preeklampsi, intrauterin gelişim kısıtlılı̆̆ı, düşük doğum ağırlı̆̆ı, iyatrojenik erken doğum gibi kötü perinatal sonuçların sıklı̆̆ını artırmakla beraber, nefrotik düzeyde proteinüri saptanan kadınlarda, daha az şiddetli proteinürisi olan kadınlara göre PE insidansı daha fazla, tanı haftası daha erken, İGP-PE arasındaki süre daha kısa saptanmıştır.

Anahtar sözcükler: Düşük doğum ağırlığı, interval, izole gestasyonel proteinüri, preeklampsi.
Correspondence: Mehmet Özgür Akkurt, MD. Perinatology Clinic, Bursa Postgraduate Training and Research Hospital, Bursa, Turkey. e-mail: mozgurakkurt@gmail.com Received: September 2, 2018; Accepted: October 19, 2018

Please cite this article as: Akkurt MÖ, Coşkun B, Güçlü T, Pakay K, Korkmazer E. Comparison of obstetric outcomes of pregnant women with isolated proteinuria according to proteinuria severity. Perinatal Journal 2018;26(3):107-111.

C2018 Perinatal Medicine Foundation
Available online at: www.perinataljournal.com/20180263002 doi: $10.2399 /$ prn. 18.0263002 QR (Quick Response) Code:

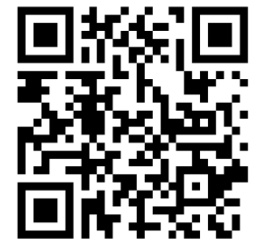




\section{Introduction}

During pregnancy, detecting proteinuria $\geq 300 \mathrm{mg} / \mathrm{dl}$ in 24-hour urine and/or finding proteinuria +1 and above in the urinalysis by dipstick method is considered abnormal and defined as isolated gestational proteinuria (IGP) ${ }^{[1]}$ Although clean and fresh urine sample can be collected by urinary dipstick method, it is affected by many clinical conditions such as protein content, infection and/or blood contamination in urine. ${ }^{[2]}$ Therefore, determining protein amount in 24-hour urine is the most appropriate method for preeclampsia. ${ }^{[3]}$

It has not been clarified yet if proteinuria is an indicator of preeclampsia which will develop in the following steps of pregnancy or a physiological change in the kidneys associated with the pregnancy or not. Although proteinuria is accepted the late finding of preeclampsia today, Morikawa et al. suggest that isolated proteinuria is an early clinical finding of PE. ${ }^{[4]}$ Until the preeclampsia report prepared by ACOG (American College of Obstetricians and Gynecologists) in 2013, proteinuria was among the diagnostic criteria of preeclampsia. ${ }^{[5]}$ After this report, proteinuria was removed from the absolute criteria of preeclampsia. In this report, it was highlighted that in $10 \%$ and $20 \%$ of pregnant women who were found to have preeclampsia or eclampsia, respectively, did not have proteinuria during the diagnosis. ${ }^{[5]}$

Hypertensive diseases are still among the major reasons of maternal and perinatal deaths, and isolated proteinuria is one of the risk factors defined for PE. Therefore, following up such patients in terms of PE development is very important. Our aim in this study is to analyze the perinatal outcomes of pregnant women who were found to have proteinuria in 24-hour urine and to investigate whether proteinuria severity and the period for PE development are associated or not.

\section{Methods}

Our study was conducted at Bursa Yüksek İhtisas Training and Research Hospital which is the biggest tertiary center in South Marmara. Pregnant women with isolated proteinuria during 54 months between January 1, 2014 and June 30, 2018 were included in the study. Proteinuria was measured in 24-hour urine of pregnant women who were found to have proteinuria +1 or above in the dipstick urinalysis according to the hospital protocol. The pregnant women with proteinuria level of 300 $\mathrm{mg}$ and above were included in the study. Since the study was based on the method of analyzing retrospective records, the approval of ethics committee was not obtained. The women with hypertension during the diagnosis, those with the history of renal and vascular diseases, the women diagnosed with diabetes before pregnancy, multiple pregnancies, the pregnant women with fetuses which had chromosomal or non-chromosomal genetic diseases and structural malformations, and the pregnant women who had risk factors for preeclampsia such as molar pregnancy were excluded from the study.

Without the history of a hypertensive disease, proteinuria and/or end organ damage accompanying to systolic blood pressure being $140 \mathrm{mmHg}$ and above and/or diastolic blood pressure being $90 \mathrm{mmHg}$ and above in the last 2 measurements with 4-hour intervals in the follow-ups after 20 weeks of gestation was defined as preeclampsia. The study group was separated into 3 groups according to the 24-hour proteinuria severity: Group 1: Physiological proteinuria (<300 mg/day); Group 2: Mild proteinuria (300-3000 mg/day); Group 3: Proteinuria at nephrotic level (3000 $\mathrm{g}$ and above). The maternal data (age, gravida, living child, 24-hour urine level, the week of proteinuria diagnosis, the week of preeclampsia diagnosis, the period elapsed between the diagnoses of proteinuria and preeclampsia) and perinatal data (the incidence of intrauterine growth retardation [IUGR], abdominal circumference [percentile], birth time, delivery type, birth weight, the rate of cesarean section due to fetal stress, newborn's hospitalization duration at intense care unit, 1-minute and 5-minute APGAR scores and perinatal mortality rate) were obtained from the files of mothers and newborns and these data were compared among the groups.

The statistical analysis was performed by using SPSS 22.0 (IBM SPSS, version 22, IBM Corp. Armork, NY, USA). The descriptive data were expressed as mean and standard deviation. Kolmogorov-Smirnov test was used to determine the distribution of variables. For the analysis of quantitative and qualitative data, Mann-Whitney $U$ and chi-square tests were used respectively. Fisher's test was used when chi-square test could not meet the conditions. Spearman's test was used for the correlation analysis and $\mathrm{p}<0.05$ was considered significant.

\section{Results}

Isolated proteinuria was found in 77 pregnant women who admitted to our clinic during the study period. The 
Table 1. The comparison of maternal and perinatal characteristics according to 24-hour proteinuria severity.

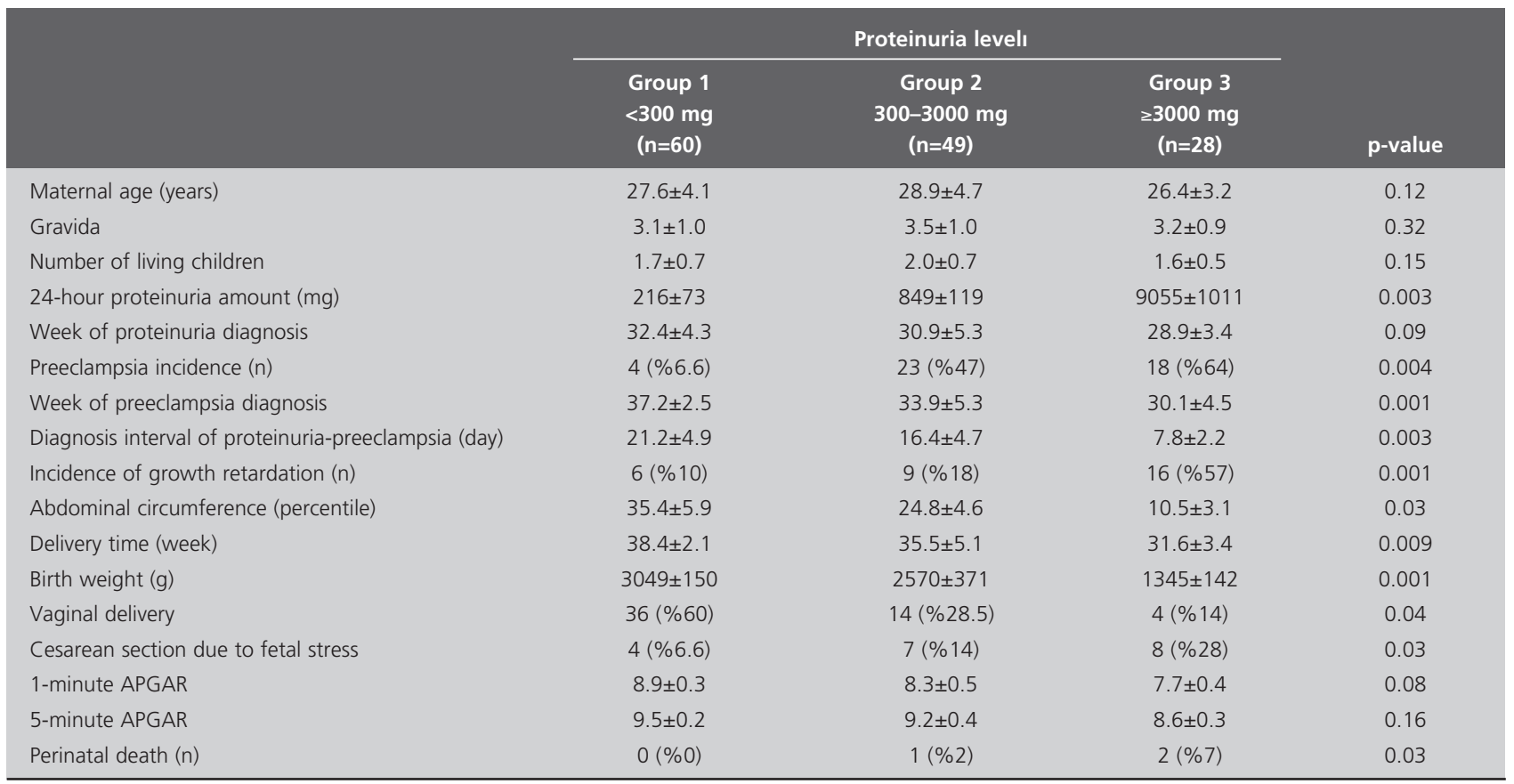

proteinuria was at nephrotic level in 28 of them $(\geq 3000$ $\mathrm{mg} /$ day) and at mild level in 49 of them. The patients with isolated proteinuria were separated into 3 groups according to their severity and when compared to the control group $(\mathrm{n}=60)$, no difference was found among 3 groups in terms of maternal age, gravida and the number of living child. Compared to the other groups, the mean proteinuria level was the highest in the group with nephrotic level $(216 \pm 73 \mathrm{mg} /$ day in Group 1, 849 \pm 119 $\mathrm{mg}$ /day in Group 2, and 9055 $\pm 1011 \mathrm{mg} /$ day in Group 3, respectively; $\mathrm{p}<0.05$ ). In 4 pregnant women included in our study, proteinuria was found $10 \mathrm{~g}$ and above in 24hour urine (range: 10.98 to $21.45 \mathrm{~g} /$ day). While all of these pregnant women also had hypertensive diseases, 2 of them had HELLP (hemolysis, elevated liver enzymes, thrombocytopenia).

In the group with proteinuria at nephrotic level, preeclampsia and growth retardation rates were also higher. Preeclampsia also developed at the earlier weeks of gestation in this group. The period elapsed between the diagnoses of proteinuria and preeclampsia was shorter in the group with proteinuria at nephrotic level compared to the other groups. In both groups with proteinuria, IUGR rate was higher and birth weight was lower than the control group. When perinatal outcomes were compared, the rate of cesarean section due to fetal stress and perinatal mortality rate was significantly higher in the group with proteinuria at nephrotic level (Table 1). When the correlation between 24-hour urine severity and birth weight, the week of preeclampsia diagnosis and the period elapsed between the diagnoses of proteinuria and preeclampsia was analyzed, a significant correlation was found between proteinuria severity and birth weight and diagnosis interval (Table 2).

Table 2. The relationship between proteinuria severity and birth weight, week of preeclampsia diagnosis and development period.

\begin{tabular}{lccc} 
& $\begin{array}{c}\text { Birth } \\
\text { weight }\end{array}$ & $\begin{array}{c}\text { Week of } \\
\text { preeclampsia } \\
\text { diagnosis }\end{array}$ & $\begin{array}{c}\text { Diagnosis } \\
\text { interval of } \\
\text { proteinuria- } \\
\text { preeclampsia }\end{array}$ \\
\hline $\begin{array}{l}\text { Proteinuria }<300 \mathrm{mg} / \text { day } \\
(n=60)\end{array}$ & $r=0.25$ & $r=-0.38$ & $r=0.16$ \\
$\begin{array}{l}\text { Proteinüri } \geq 300 \mathrm{mg} / \text { day } \\
(n=77)\end{array}$ & $r=0.68^{*}$ & $r=0.22$ & $r=0.79 *$ \\
\hline
\end{tabular}

The relationship was calculated by Spearman's correlation coefficient. Statistically significant values were expressed by the symbol *. While a moderate and significant correlation and significant correlation was found between proteinuria at cant correlation and significant correlation was found between proteinuria at
nephrotic level and birth weight, there was a strong and significant correlation in the diagnosis interval between proteinuria and preeclampsia. 


\section{Discussion}

Distinguishing isolated gestational proteinuria and preeclampsia is very important for the management of gestation. In a study performed $\left({ }^{[6]}\right.$ incidences for preterm labor, low birth weight, gestational diabetes and renal disease in women with IGP were found similar with the healthy women, and these women had term labor. On the other hand, preeclampsia is associated with increased maternal and perinatal morbidity. Our study is a retrospective case-controlled study performed in a tertiary center. According to our results, the risk of increased preeclampsia and intrauterine growth retardation increases in pregnant women who are found to have isolated proteinuria. Also, there is a significant correlation between proteinuria and birth weight and the period elapsed between the diagnoses of proteinuria and preeclampsia.

The most common method to determine the presence of proteinuria is the urinalysis by dipstick test. However, false positivity rate increases in some clinical conditions such as concentrated urine or concurrent infection. ${ }^{[7]}$ Although collecting urine in 24 hours and analyzing it as in our study is the golden standard for IGP, it usually cannot be tolerated by the patients since the procedure takes long. As found by Yamada et al., protein/creatinine rate above 0.27 in the spot urine is an easy and useful method for the diagnosis of IGP. ${ }^{[8]}$

While the incidence of isolated proteinuria varied in the previous studies, it was seen in about $2 \%$ (range: 0.3 to $4 \%$ ) of pregnancies and its importance could not be understood clearly. ${ }^{[7-9]}$ Proteinuria is not seen during the diagnosis in approximately $15-26 \%$ of pregnant women with new-onset hypertension, but it is found in the further phases of the pregnancies. ${ }^{[10,11]}$ As argued by Akaishi et al., preeclampsia develops in 2 different conditions: (1) when proteinuria is diagnosed much earlier than hypertension, or (2) proteinuria and hypertension are diagnosed at the same time. ${ }^{[9]}$ Increased body mass index, twin pregnancy, nulliparity, young maternal age which are among the well-known risk factors for $\mathrm{PE}$ are also the risk factors for GP, and supports this hypothesis. ${ }^{[12]}$

The progression rate of $\mathrm{PE}$ in women with IGP varies among the studies. The reasons for this difference among the studies include the size of population and mean week of gestation, PE incidence and the risk factors of women in the study population. Morikawa et al. ${ }^{[1]}$ found $\mathrm{PE}$ in about $51 \%$ of the pregnant women diagnosed with isolated proteinuria in their retrospective review and this rate was $34 \%$ in the study of Ekiz et al. ${ }^{[7]}$ In the study of Yamada et al., the authors found that PE developed in $25 \%$ of the patients with IGP, and $20 \%$ of all PE patients developed PE after IGP was diagnosed. ${ }^{[8]}$ In our study, we diagnosed PE in later periods in $53 \%$ of the women with proteinuria level of $300 \mathrm{mg}$ and above. In the sub-group analysis according to the proteinuria severity, we found that $\mathrm{PE}$ was concomitant in $64 \%$ of those with proteinuria at nephrotic level and in $47 \%$ of those with less severe proteinuria (between 300 and 3000 $\mathrm{mg})$. In addition, the week of $\mathrm{PE}$ diagnosis was earlier and the period elapsed between the diagnoses of isolated proteinuria and preeclampsia was shorter in the group with proteinuria at nephrotic level. Many studies investigated the risk factors for this progression. Twin pregnancy, pregnancy after 40-year-old, preeclampsia history and nulliparous women are also in the risk group. ${ }^{[7,13]}$ In addition to these studies, we also found a significant correlation between proteinuria severity and the week of preeclampsia diagnosis and diagnosis interval.

The single-center study ( $\mathrm{n}=37)$ of Morikawa et al..$^{[1]}$ which included a limited number of pregnant women with IGP and the multi-centered large-scale study $(n=130)$ of Yamada et al.$^{[8]}$ similarly found PE about 2 weeks after diagnosing IGP. Unlike other studies, we found in our study that $\mathrm{PE}$ developed about 8 days later in the cases with proteinuria at nephrotic level and about 16.5 days later in the cases with less severe proteinuria. Our study contributes to the literature and shows that the period of $\mathrm{PE}$ development is also significantly correlated with the proteinuria severity.

Similar to the study of Ekiz et al., ${ }^{[7]}$ we showed that IGP is not only associated with the increased PE risk but also with the increased risk of growth retardation and low birth weight. This shows that further wide-scale studies investigating the relationship between IGP and increased poor obstetric outcomes are needed. The major limitation of study is its retrospective nature. Being single-centered and having limited number of patients are the factors affecting the incidence of preeclampsia. In addition, since it is retrospective, we could not obtain some information such as increased body-mass index, history of previous PE, weight gain during pregnancy, the history of aspirin use, increased resistance in uterine artery Doppler blood flow which may contribute to the development of preeclampsia. Also, we did not investigate maternal outcomes as we focused on perinatal outcomes. However, the studies in 
the literature which estimate PE development according to the proteinuria severity are limited.

\section{Conclusion}

According to the findings of our study, women with IGP are in the risk group in terms of increased poor perinatal outcomes. In these women, the risk for preeclampsia, low birth weight and iatrogenic preterm labor is increased. PE incidence is higher, diagnosis week is earlier and the period elapsed between the diagnoses of IGP and $\mathrm{PE}$ is shorter in women with proteinuria at nephrotic level compared to the women with less severe proteinuria. Therefore, we recommend follow up the women with proteinuria at nephrotic level closely due to the increased risk of $\mathrm{PE}$ and growth retardation and expect the development of $\mathrm{PE}$ about 8 days after IGP diagnosis at nephrotic level.

Conflicts of Interest: No conflicts declared.

\section{References}

1. Abalos E, Cuesta C, Grosso AL, Chou D, Say L. Global and regional estimates of preeclampsia and eclampsia: a systematic review. Eur J Obstet Gynecol Reprod Biol 2013;170:1-7.

2. Levine RJ, Ewell MG, Hauth JC, Curet LB, Catalano PM, Morris CD, et al. Should the definition of preeclampsia include a rise in diastolic blood pressure of $>/=15 \mathrm{~mm} \mathrm{Hg}$ to a level $<90 \mathrm{~mm} \mathrm{Hg}$ in association with proteinuria? Am J Obstet Gynecol 2000;183:787-92.

3. Thadhani RI, Maynard SE. Proteinuria in pregnancy: evaluation and management. In: Post $\mathrm{T}$, editor. UpToDate. [Internet]. Waltham, MA: UpToDate; 2017 [cited August 15, 2017]. Available from: www.uptodate.com
4. Morikawa M, Yamada T, Minakami H. Outcome of pregnancy in patients with isolated proteinuria. Curr Opin Obstet Gynecol 2009;21:491-5.

5. American College of Obstetricians and Gynecologists; Task Force on Hypertension in Pregnancy. Hypertension in pregnancy. Report of the American College of Obstetricians and Gynecologists' Task Force on Hypertension in Pregnancy. Obstet Gynecol 2013;122:1122-31.

6. Holston AM, Qian C, Yu KF, Epstein FH, Karumanchi SA, Levine RJ. Circulating angiogenic factors in gestational proteinuria without hypertension. Am J Obstet Gynecol 2009; 200:392.e1-10.

7. Ekiz A, Kaya B, Polat I, Avci ME, Ozkose B, Kicik Caliskan R, et al. The outcome of pregnancy with new onset proteinuria without hypertension: retrospective observational study. J Matern Fetal Neonatal Med 2016;29:1765-9.

8. Yamada T, Obata-Yasuoka M, Hamada H, Baba Y, Ohkuchi A, Yasuda S, et al. Isolated gestational proteinuria preceding the diagnosis of preeclampsia - an observational study. Acta Obstet Gynecol Scand 2016;95:1048-54.

9. Akaishi R, Yamada T, Morikawa M, Nishida R, Minakami H. Clinical features of isolated gestational proteinuria progressing to pre-eclampsia: retrospective observational study. BMJ Open 2014;4:e004870.

10. Saudan P, Brown MA, Buddle ML, Jones M. Does gestational hypertension become pre-eclampsia? Br J Obstet Gynaecol 1998;105:1177-84.

11. Morikawa M, Yamada T, Yamada T, Cho K, Yamada H, Sakuragi N, et al. Pregnancy outcome of women who developed proteinuria in the absence of hypertension after mid-gestation. J Perinat Med 2008;36:419-24.

12. Kuyucu M, Arınkan SA, Herkiloğlu D, Muhcu M. Assessment of maternal and perinatal outcomes in pregnant women with isolated proteinuria. Perinatal Journal 2016;24:129-35.

13. Macdonald-Wallis C, Lawlor DA, Heron J, Fraser A, Nelson SM, Tilling K. Relationships of risk factors for pre-eclampsia with patterns of occurrence of isolated gestational proteinuria during normal term pregnancy. PLoS One 2011;6:e22115. 